\title{
GLOBALIZATION AND LOCALIZATION: THE FORMATION OF THE TECHNOLOGY INNOVATIVE DEVELOPMENT
}

\author{
Natalya Gagulina ${ }^{1}$, Irina Zhulega ${ }^{2, *}$, and Alexandr Samoylov ${ }^{3}$ \\ ${ }^{1}$ ITMO University, Faculty of Technological Management and Innovations, Department of \\ Economics and Strategic Management, Saint Petersburg, 197101, Russia. \\ ${ }^{2}$ State University of Aerospace Instrumentation, Institute of Enterprinership Technologies, \\ Department of High-Tech Sistems Security, Saint Petersburg, 190000, Russia. \\ ${ }^{3}$ State University of Aerospace Instrumentation, Institute of Enterprinership Technologies, Head of \\ Department of High-Tech Sistems Security, Saint Petersburg, 190000, Russia.
}

\begin{abstract}
Future of the global economy depends more and more on possibilities and restrictions of innovative development. In the classical interpretation economic development is limited by non-renewable nature of a significant part of the natural resource potential and assimilation abilities of the environment. In opposition, it's safe to say that the impact of innovative-technological factors, based on scientific, educational and information revolutions, powered by the synergic effect of the partnership of civilizations, is rising. The aggravation of this global contradiction forces countries, regions and enterprises around the world to look for additional ways to increase competitiveness and efficiency. One of the possible ways to solve this problem is the development of cluster policy both on the part of the state and on the part of business, large multinational companies. The article analyzes the possibility of formation of technology of innovative development of the region through the competent implementation of cluster policy. The authors conducted a systematic analysis of the effects of clustering (localization), concentrated in the field of high-tech industries, identified problems of their development, including those in the context of globalization.
\end{abstract}

\section{Introduction}

The modern structure of the world economy, conditioned by the contradictory integrity of world economies and regions linked by international economic relations, is imperfect. The negative effects arising in the process of international interaction make the formation of innovative development technology in countries with economies in transition and developing countries problematic. Thanks to their financial and production capabilities, TNCs concentrate knowledge-intensive production, contributing to the improvement of technologies, the development of regional interactions. The competitive advantages of

\footnotetext{
* Corresponding author: zhulega@mail.ru
} 
globalization-saving on production scale, increasing of labour efficiency and others-are accompanied by the challenges posed by the activities of transnational corporations. The increasing economic polarization of the world, the technological gap between rich and poor countries, regional differentiation within countries play a decisive role in the activation of innovation processes. In this regard, it is vital to change the current model of search, implementation and development of innovations in countries that are concerned about the prospects for further innovative development.

Interest in clustering processes is due to the advantages of concentration, which effective integration of financial and intellectual potential creates. Under adequate institutional conditions, such advantages ensure the competitiveness of the region and contribute to improving the quality of life not only at the present time, but also in the long term.

\section{Opportunities and limitations of innovative development, globalization}

For almost a quarter of a century, analysts have identified such areas as ideology, formal and informal institutions, consumption and sales, markets for goods and services, financial markets, accumulation and investment, the labour market, science and innovation, ecology, and reproduction processes as the main components of the development of the modern world economy [1]. To a large extent, this is facilitated by globalization, which has spread on the basis of information and communication technologies since the second half of the 1980s. [2].

With the acceleration of scientific and technological progress since the mid-80s of the $\mathrm{XX}$ century, the uneven development of the world countries became more noticeable. The world economy today is characterized by different levels of development of production factors in more than 200 countries, permanent technological shifts and changes in the sphere of production, labour and other social relations [3]. At the beginning of the transformation period of perestroika in Russia, the general standard of living of the population was three times higher than the standard of living in China and Brazil and corresponded to the level of life of almost half of the current EU countries. The series of economic crises that the Russian economy has undergone since then has caused a decline in living standards in the country and regions, and the quality of life has changed. The contribution of globalization to the fall in living standards should also be noted [4].

Low-income countries, home to nearly 1.3 billion people, lack necessary science and technology basis, investment and skills to implement innovative change. For comparison: in 1950, the productivity gap between North American and African civilizations was 32.1 times, today it has almost fallen by one half, but even this gap is still too high [5]. At the same time, the activities of transnational corporations are accompanied by the flow of world rents, anti-rents and quasi-rents to the accounts of TNCs in rich countries, aggravating the generally unstable situation in the world economy, which affects the Russian economy due to its deep involvement in international exchange [6].

The situation with the distribution of national wealth in Russia, where almost a quarter of a century TNCs lead their economic activity, is as follows. Less than $0.5 \%$ of the population accounts for more than $70 \%$ of the national wealth, Russia is among the most unjust societies. With this background, huge financial resources are being withdrawn from the country, which, according to various sources, are measured to be from $50-75 \%$ to $200 \%$ of annual GDP. These data illustrate the problem of compatibility between globalization and localization: the financial resources that left the country in the global economic space could be successfully used to localize innovations, create clusters and, ultimately, improve national competitiveness [7]. 
As the experience of developed countries shows, one of the most effective elements of the creation and introduction of new technologies is territorial innovation system. It allowsto localize the innovation cycle within the territories with the greatest potential for creation and implementation of innovations. In the context of sanctions, Russian companies need to create new technologies, ways of organizing production in the country [8]. The experience of clustering, widespread in the European Union, is of particular interest. According to some data, countries actively using cluster strategies were able to achieve GDP growth in the range of 75 to $90 \%$ [9]. The main branches of clustering: electronic technologies and communications, computer science, biotechnology and bioresources, pharmaceuticals and cosmetics, agricultural and food production, oil and gas industry and chemistry, engineering, electronics, health care, etc. [10].

\section{Opportunities for establishment of technology of innovative development of the region}

The idea of the cluster approach is to create a management technology that will increase the competitiveness not only of a particular region or industry, but also of the entire country. The interest in clustering processes is due to the advantages created by the effective integration of financial and intellectual potential. In adequate institutional conditions, such advantages ensure the competitiveness of the region not only at the current time, but also in the long term [11]. The attractiveness of this technology is due to the possibility of building a closed technological chain within the cluster, starting with the idea of creating a product and ending with its introduction to the market. Breakthrough ideas implemented on the basis of clusters have significant innovative potential and create factors for economic growth. The creation of clusters is a progressive form of innovation. Over the past 15 years, innovations in business models have attracted increasing attention in management research and among practitioners [12].

Innovation cluster is a system of relationships between universities, commercial enterprises, research centers, technology parks, business incubators, venture capital funds, government agencies, etc., which allows to use the advantages of integration, scale and synergy to improve the efficiency of the processes of creation, spread and commercialization of new knowledge and inventions.

The process of creating a regional innovation cluster includes several stages:

- the formation of a working group from the people overtaken by the pioneering spirit;

- the setting of goals and key objectives;

- the development of legal and organizational basis for the work of the cluster;

- scenario analysis of the innovation system development with the forecast of prospects of its functioning and development;

- monitoring the work and identifying possible improvements.

The key directions of development of regional clusters are determined by the interests of its main participants: the state, universities and businesses. Here it is appropriate to refer to the triple helix model [13]. This model was proposed as a basis for the study of territorial social-economic systems at the regional level in European countries. It has an applied nature and is often used for the implementation of regional innovation policy.

The triple helix model has the form of a social structure that unites three institutions: the state, universities and business (Fig. 1). 


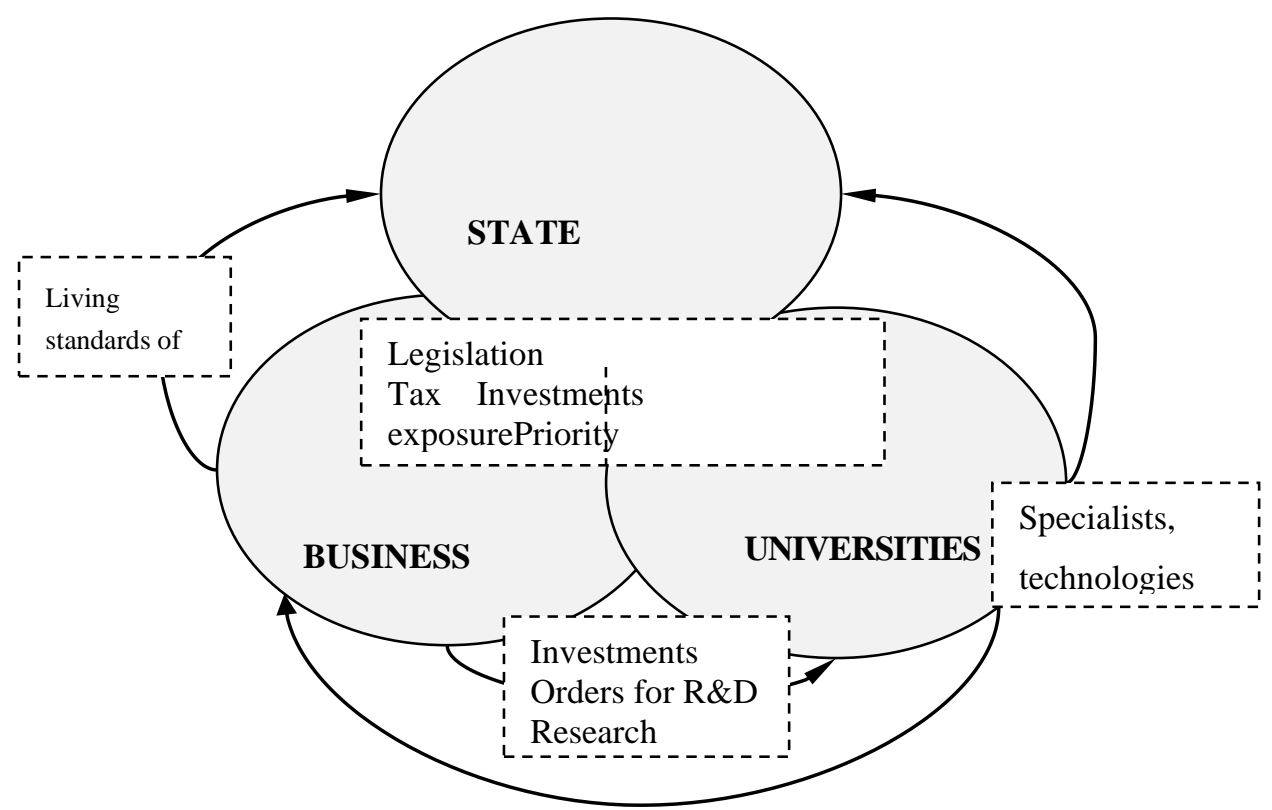

Fig. 1. Model of interaction between businesses, government and universities in the region [14]

Further development of the cluster takes place in several stages [14], presented in Fig. 2.
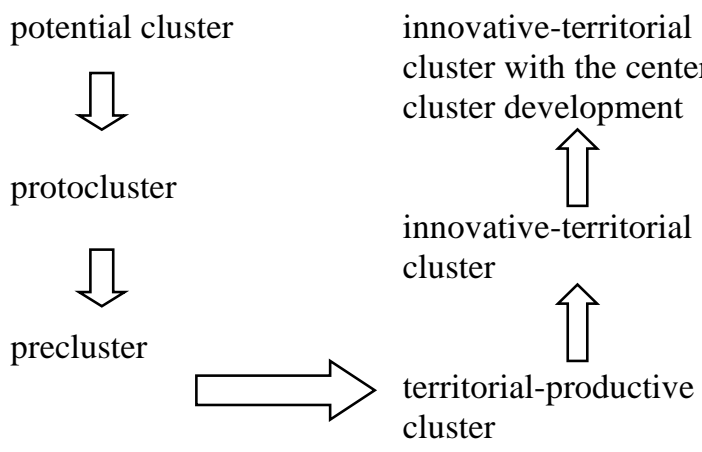
effective
innovative-
territorial cluster
with the center of
cluster
development

Fig. 2. Cluster formation stages [14]

Each stage has its own distinctive characteristics.

At the initial stage, the cluster is a group of firms of one industry concentrated in one territory, and by the time it turns into an effective innovative-territorial cluster with the center of cluster development, it is already a group of interacting firms concentrated in one territory, one or more technologically interconnected industries within a single scientific and production complex and with a management structure, forming a highly effective system due to the manifestation of synergetic (cluster) effects [15].

In order to analyze trends in the development of high-tech clusters in the regions of Russia, we will use the data of the Russian cluster observatory of the NRU HSE Institute for statistical research and knowledge-based economics [16]. As of the beginning of 2019, 88 clusters were registered in Russia, which is 18 units more than in 2016 (here and further information on the North Caucasus Federal district is not available). The most active cluster formation occurs in the Central Federal district, in the second place - the Volga Federal 
district, the third - the Siberian (Fig. 3). The increase in innovation activity within clusters in the regions of Russia is uneven.

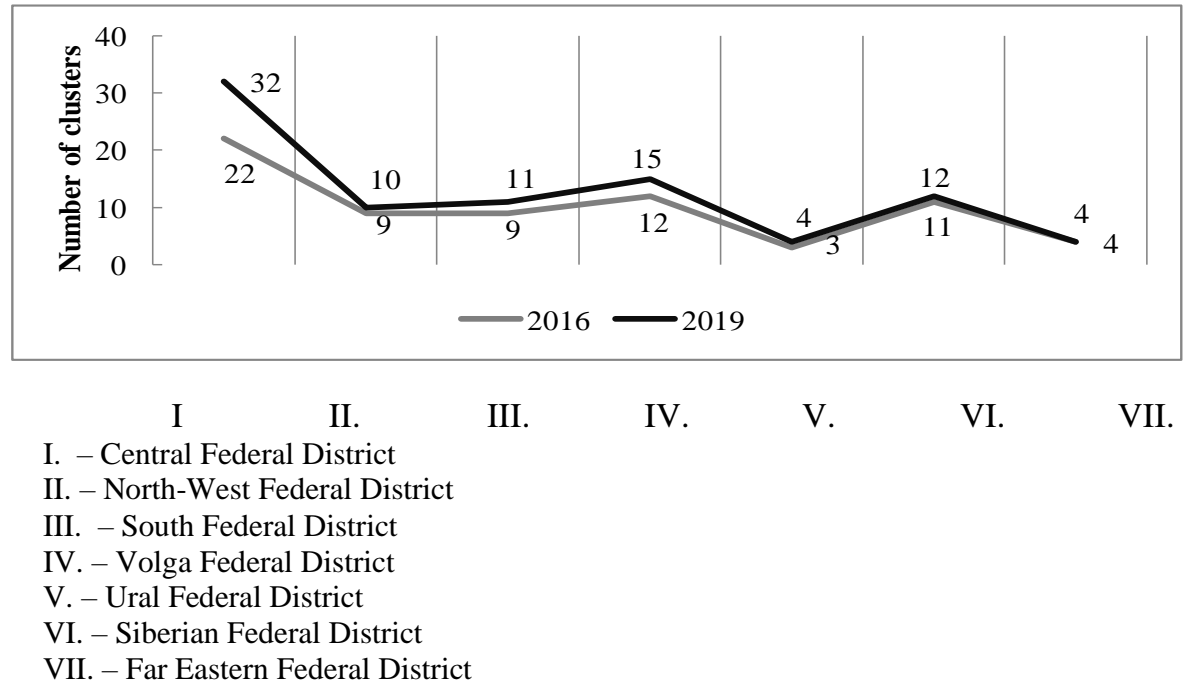

Fig. 3. Change in the number of clusters by Federal District [16]

The number of regions in which clusters function, has also increased over the past three years by 9 units. The greatest number of clusters is concentrated in Rostov region, the Republic of Tatarstan, Moscow and Saint Petersburg, Voronezh region. The least number of clusters (3)was in the Ural Federal Districtin 2016, and in 2019 - 4 clustersin the Far Eastern Federal District.

In the period under review, both the number of participating firms and the number of employees in clusters increased (figures 4.5). If in 2016 784,3 million people worked in 1675 companies, in 2019 it is already 1591,8 thousand people in 3815 firms.

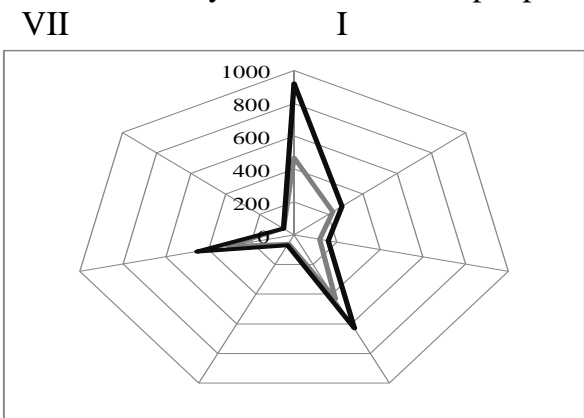

VI

$\mathrm{V}$

VI

I. - Central Federal District

II. - North-West Federal District

III. - South Federal District

IV. - Volga Federal District

V. - Ural Federal District

VI. - Siberian Federal District

VII. - Far Eastern Federal District

Fig. 4. Change in the number of participating firms by Federal District [16] 
The Republic of Tatarstan has the largest number of participating firms and employees in 2019 , with $12.9 \%$ of all firms participating in clusters and $13.3 \%$ of total number of people employed.

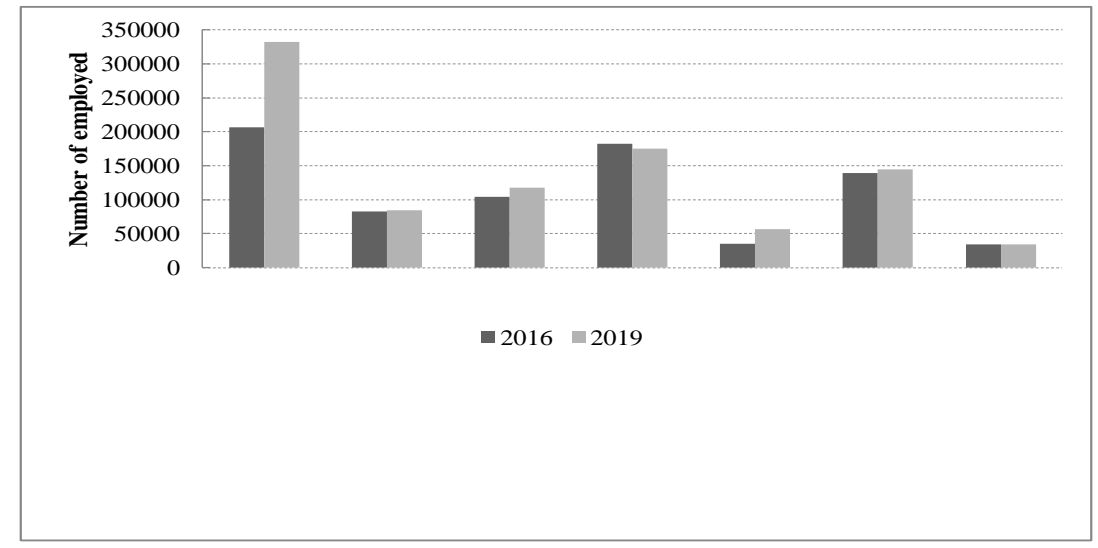

\section{$\begin{array}{lllllll}\text { I } & \text { II } & \text { III } & \text { IV } & \text { V } & \text { VI } & \text { VII }\end{array}$}

I. - Central Federal District

II. - North-West Federal District

III. - South Federal District

IV. - Volga Federal District

V. - Ural Federal District

VI. - Siberian Federal District

VII. - Far Eastern Federal District

Fig. 5. Change in the number of people employed in clusters by Federal Districts [16]

Megalopolises Moscow and Saint Petersburg traditionally occupy a strong position among the leaders: they account for $5 \%$ and $7 \%$ of the total number of people employed, respectively. In general, during the period under examination, new points of increase appeared in the Bryansk region, Murmansk region, Astrakhan region, Tyumen region, Komi Republic, Udmurt Republic, etc. This is largely facilitated by the state's proactive cluster policy, which has intensified the emergence of agglomeration and localization effects in the regional economy [17].

The quality of life is determined by the combination of factors of human existence and development. The need to meet the cultural (spiritual) and social needs of citizens explains the qualitative content of this concept [18, 19]. It manifests itself through the ease or difficulty of satisfying human needs: individual and social. The system of indicators of the quality of life, namely the level of income of the population - how much and to what extent income provides satisfaction of material and spiritual needs of people - allows to form an opinion about the possibilities of meeting the needs [20]. In addition to the level of income and consumption of material goods, the standard of living is largely determined by the availability of housing. This is even more important because the marginal propensity to consume from temporary income increases the cost of housing [21].

The expediency of discussing innovations in this perspective is explained by positive external effects generated by innovative activity [22]. 


\section{Discussion}

The spread and wide use of information and communication technologies provides a powerful impulse for globalization [23]. Giant accumulators of innovative development on a world-wide basis are TNCs actively using the effects of localization from the beginning. Along with increase of productivity, impact of scale and other benefits for the country in which TNCs operate, there are widespread negative effects of their operations [24]. The selective use of innovative technologies by transnational corporations makes the economies of such countries vulnerable and creates conditions for strengthening the technological gap with the leading economic powers [25].

In our opinion, the technology of innovative development mostly consists of localization, which provides an increasing return with production concentration. In this regard, the triple helix model which illustrates the localization of the innovation cycle and its institutionalization in the interests of the national economy as a result of partnership between universities, businesses and government (represented by the state) is of particular interest. The applied nature of the model allows to use it for the implementation of regional investment policy [26]. The generation of knowledge and innovation which creates the basis for the financial flowis carried out by universities and research centers. The greater the flow of knowledge is, the more innovative technologies are created in the country [27]. Financial and knowledge flows are structured information-based flows that can and should be used to manage the latest technologies for innovative development.

\section{References}

1. R. I. Khasbullatov. Modernizatsiya ekonomicheskih system I innovatsii: usloviya I predposylki. [Economic systems modernization and innovations: conditions and background] // REA Bulletin. 4, 31-38 (2011).

2. E.R. Banalieva \& Dhanaraj. Journal of International Business Studies. Internalization theory for the digital economy. (2019)

3. J. Song, D. Price, F. Guvenen, N. Bloom, T. von Wachter. The Quarterly Journal of Economics. Firming Up Inequality. 134(1), February 2019. 1-50, (2019)

4. W. Kopczuk, E. Saez, J. Song. The Quarterly Journal of Economics. Earnings Inequality and Mobility in the United States: Evidence from Social Security Data Since 1937. 125(1), February 2010, 91-128, (2010).

5. World economics. Global tendencies for 100 years. / Edited by I. S. KorolevMoscow: Yurist. 539-540, (2003).

6. A. Bell, R. Chetty, X. Jaravel, N. Petkova, J. van Reenen. The Quarterly Journal of Economics. Who Becomes an Inventor in America? The Importance of Exposure to Innovation. 134, 2, May 2019, 647-713, (2019)

7. Government resolution of the RF dated 17.11.2008. 1662-p «On the concept of longterm social-economic development of the Russian Federation for the period up to 2020», http://government.ru/docs/9282/ (2019)

8. Strategy of the innovation development of the Russian Federation for the period up to 2020. URL: http://government.ru/docs/9282/ (2019)

9. O. Ioffe. Klasterniy podkhod [Cluster approach] // Provincial business magazine. 11. 19, (2009)

10. E. B. Lenchuk, G. A. Vlaskin. Cluster approach in the strategy of innovation development of the foreign countries. URL: 
https://cyberleninka.ru/article/v/klasternyy-podhod-v-strategii-innovatsionnogorazvitiya-zarubezhnyh-stran (2019)

11. N.M. Abdikeev and others. Innovatsionnoye razvitiye Rossii: problem I resheniya: monografiya [Innovation development of Russia: problems and solutions: monograph]/ Collective of authors. - Moscow.: Ed. 2nd, revision and add. 1376. (2014)

12. N.J. Foss, T.Saebi. Journal of Management. Fifteen Years of Research on Business Model Innovation: How Far Have We Come, and Where Should We Go? 43(1), 23 November 2016. 200-227, (2016)

13. I.G. Triplehelix. Universities - enterprises - state. Innovations in action: translation from English. / G. Itskovits; trans. A. F. Uvarov. - Tomsk: PublishingofficeTUSUR. 238, (2010)

14. S.P. Zemtsov, D.V. Bukov. Metody vyiavleniya klasterov malogo I srednego bisnesa [Methods of identifyinf clusters in small and medium-sized business] / Regional economics: theory and practice. 3. 104-117, (2016)

15. L.M. Gokhberg, A.E. Shadrin. Pilotnye innovatsionnye territorialnye klastery $v$ Rossiyskoy Federatsii [Pilot innovative-territorial clusters in the Russian Federation.Moscow. 19. (2013)

16. Russian cluster observatory of the NRUHSE Institute of statistic research and knowledge-based economics. URL: https://map.cluster.hse.ru/ (2019)

17. V.V. Okrepilov. Perspektivy sozdaniya mnogourovnevoy sistemy upravleniya kachestvom [The perspectives of creation of the multilevel system of quality management]// Standards and quality. 1. 58-65. (2009)

18. M.K. Chan. The Review of Economic Studies. Welfare Dependence and Self-Control: An Empirical Analysis. 84(4), 1 October 2017. 1379-1423, (2017)

19. N. Beck, A. Swaminathan, J. Wade, F.C. Wezel. Journal of Management. Industry clusters and organizational prototypes: Evidence from the Franconian brewing industry. 45(7), September 2019 NP2 (2019)

20. A. Falk, A. Becker, T. Dohmen, B. Enke, D. Huffman. The Quarterly Journal of Economics. Uwe Sunde Global Evidence on Economic Preferences. 133(4), 1 November 2018, 1645-1692, (2018)

21. D. Berger, V. Guerrieri, G. Lorenzoni, J. Vavra. The Review of Economic Studies, House Prices and Consumer Spending. 85(3), 1 July 2018. 1502-1542, (2018)

22. Kumaraswamy, Arun; Garud, Raghu; Ansari, Shahzad (Shaz) Journal of Management Studies. Perspectives on Disruptive Innovations. 55(7), 1 November 2018. 1025-1042, (2018)

23. M.A. Fox, Drive-in theatres, technology, and cultural change, Economics, Management, and Financial Markets 13, 24-39 (2018)

24. E. Nica, C. Manole, C.I. Stan, A laborless society? How highly automated environments and breakthroughs in artificial intelligence bring about innovative kinds of skills and employment disruptions, altering the nature of business process and affecting the path of economic growth, Journal of Self-Governance and Management Economics 6, 25-30 (2018)

25. V. Spitsin, A. Mikhalchuk, N. Chistyakova, L. Spitsyna, I. Pavlova, Development of innovative industries in Russia under unfavourable external environment, Equilibrium. Quarterly Journal of Economics and Economic Policy 13, 467-485 (2018) 
26. A. Lewandowska, M. Stopa, SMEs innovativeness and institutional support system: The local experiences in qualitative perspective. Polish case study, Oeconomia Copernicana 9, 333-351 (2018)

27. G.H Popescu, I.E. Petrescu, O.M. Sabie, M. Mușat, Labor-displacing technological change and worldwide economic insecurity: How automation and the creation of innovative tasks shape inequality, Psychosociological Issues in Human Resource Management 6, 80-85 (2018) 